\title{
BIOWASTE SEPARATION AT SOURCE AND ITS LIMITATIONS BASED ON SPATIAL CONDITIONS
}

\author{
Jan Slavík ${ }^{1, *}$, Kristýna Rybová ${ }^{2}$ and Martin Dolejš ${ }^{2}$ \\ ${ }^{1}$ IEEP, Institute for Economic and Environmental Policy, Jan Evangelista Purkyne University, Moskevská 54, 400 96, Ústí nad Labem, \\ Czech Republic \\ ${ }^{2}$ Department of Geography, Jan Evangelista Purkyne University, České mládeže 8, Ústí nad Labem, Czech Republic
}

Article Info:

Received:

6 December 2018

Revised:

17 January 2019

Accepted:

25 January 2019

Available online:

31 March 2019

Keywords:

Biowaste collection

Public involvement

Information campaign

Location

\begin{abstract}
The European regulation of biodegradable municipal waste (biowaste) treatment places a significant demand on local biowaste separation systems and consequent treatment (composting, anaerobic digestion). When implementing separate collection systems, there is a public demand for systems based on containers and bags. Based on a case study of the city Ústí nad Labem in the Czech Republic, the authors illustrate the difficulties encountered in the implementation of this kind of system. A series of factors should be paramount in the organization of biowaste separate collection, including the location of containers, the amount of contaminants, and system parameters (e.g. volume of containers, frequency of collection). The results obtained confirm how a precision-targeted information campaign may contribute towards reducing contamination of biowaste container content. Lower amounts of contaminants imply a simplified biowaste treatment (composting) and increased system efficiency. Furthermore, it was observed that the relocation of biowaste containers, or placing of additional containers in the system, resulted in an increase in public involvement as a result of the added convenience of separate collection proximity of containers. The equipment of the chosen city district by additional 55 containers increases the number of address points covered by the system by approx. $149.20 \%$ and the number of inhabitants by about $38.14 \%$. However, this added convenience of separate collection is not cost-neutral, with the increased proximity of containers contributing towards a rise in collection costs including transport, and containers. The increase of collection costs ranges between 105.5 and $156.78 \%$ in comparison with the current situation.
\end{abstract}

\section{INTRODUCTION}

The European regulation of biodegradable municipal waste (biowaste) treatment places a significant demand on local biowaste separation systems and consequent treatment (composting, anaerobic digestion). As established by the Ordinance $321 / 2014$ relating to the extent and provision of municipal waste separate collection all Czech municipalities are required to implement a biowaste separate collection system according to the following means: a) recycling centres, b) facilities for aerobic digestion, c) bulky waste containers, d) containers, e) bags, f) a combination of a) to e). To reflect vegetative season, weather conditions, and economic limitations of small municipalities the separate collection of biowaste (according to the Ordinance with a focus on plant-originated biowaste ) should be guaranteed from April $1^{\text {st }}$ to October $31^{\text {st }}$ as a minimum requirement. For economic reasons municipalities tend to view recycling centres as the most efficient solution. However, the effectiveness of source separation and public demand calls for systems of separate collection based on containers and bags.

Although pilot studies in the Czech Republic have indicated several key factors of the successful implementation of separate collection, considerable uncertainty remains with regard to other elements of the system, particularly when the trade-off between public demand, or expectations and economic efficiency is involved. The location of containers throughout the city seems to be crucial and should reflect ready availability for the population on the one hand, whilst focusing on collection technology on the other (e.g. collection vehicles). Furthermore, with regard to the economics of collection, an optimal routing also plays a significant role in planning the location of containers. Simonetto and Borenstein (2007) reported how routing optimization based on a reduced number of collections would contribute towards minimizing the costs of collection. 
However, an effective planning of a biowaste separate collection system is not underpinned solely by the ready availability of containers; the degree of contamination of the container contents will likewise affect the efficiency of the entire biowaste treatment system. Accordingly, additional external factors should be reflected in the location of biowaste containers, including type of housing, distance from collection points of other types of separate collection (paper, glass, and plastics), frequency of separate collection etc.

Based therefore on the case study conducted in Ústí nad Labem (93,000 inhabitants, 4 districts), the authors assessed the effectiveness of biowaste separate collection systems and the degree of public involvement. Furthermore, using GIS-based systems as a suitable instrument for the purpose of increasing the efficiency of collection systems (see Rada et al., 2013), the authors impart a series of recommendations relating to optimization of the collection system. Last but not least, the effectiveness of information campaigns in reducing the degree of contamination in the city districts selected is evaluated.

\section{FACTORS INFLUENCING THE SEPARATE COLLECTION OF BIOWASTE}

\subsection{Biowaste separate collection - current experience}

Generally, the optimization of separate collection systems is based on two fundamental strategies: 1) raising system effectiveness (particularly the rate of separate collection), and 2) increasing system efficiency (cost optimization). European municipalities therefore are facing a dual challenge: to implement systems that help to meet targets established by European environmental regulations and to balance the municipal waste management budgets. Based on a bi-objective model for developing countries, Amposah and Salhi (2004) concluded that optimizing the routing and location of containers throughout the municipality may solve both problems simultaneously.

However, not all factors impinging on the effectiveness and efficiency of separate collection are controlled directly by the municipality. Dahlén and Lagerkvist (2010) divide the latter into factors that can be controlled by local/ regional waste management strategies as types of waste collected separately close to the property or with bring systems, availability of alternative places for discharge - e.g. recycling centers, or implementation of collection charges, factors that can be controlled by national waste management strategies, and factors that are beyond the possibility of control such as residential structures, household economy, or family life cycle. Therefore, and particularly in the case of residential structures, separate collection systems may need to be adapted to extrinsic conditions.

By focusing on internal factors municipalities should attempt to identify means of reaching a compromise taking into account the concerns of the population who want to confer waste with the minimum amount of inconvenience, and of disposal operators who need waste to be conferred so as to conform to treatment requirements (Gallardo et al., 2010). Therefore, the availability of the population to adhere to the separate collection system is crucial. Dis- tance to containers (Sidique et al., 2010; or Struk, 2017), lack of space in households (Domina and Koch, 2002; González-Torre and Adenso-Díaz, 2005; or Bernstad et al., 2013), lack of time to separate waste (e.g. Hage and Söderholm, 2008), or location of containers (Mattson Petersen and Berg, 2004; González-Torre et al., 2003; or GonzálezTorre and Adenso-Díaz, 2005) are all deemed to be significant drivers of separate collection. Sidique et al. (2010) reported how the closer the containers were to the place of residence, the greater the number of households participating in separate collection, largely due to the lesser time effort required (González-Torre et al., 2003). For this reason, curbside collection is frequently preferred over collection points (drop-off collection) when designing a separate collection system (Domina and Koch, 2002; Saphores and Nixon, 2014). However, when collection points are introduced, smaller containers at multiple street locations are preferred over large containers in strategic locations (González-Torre et al., 2003). Furthermore, the infrastructure needed for separate collection also plays a significant role. Bernad-Beltrán et al. (2014) confirmed that the willingness of the population to participate in the separate collection of biowaste increased when households were provided with specific bins and bags.

The willingness of households to take part in biowaste separate collection schemes may be reduced by the implementation of weight-based charging schemes and frequently results in a high rate of impurities (Dahlén et al., 2007). Furthermore, with curbside collection, Gallardo et al. (2010) pointed out that the quality of biowaste collection is lower in the presence of closely situated mixed waste bins. Rousta et al. (2015) concluded that by arranging collections in close proximity to properties, the contamination of residual wastes by recyclables (packaging, newsprint) decreased significantly. Furthermore, following the introduction of information stickers, the amount of mis-sorted fractions in food waste bags also decreased (approximately $70 \%$ ), thus leading to the conclusion that new communication channels played a key role in encouraging the sorting of waste.

Although regulatory pressures force municipalities to implement the separate collection of biowaste to divert organic matter from landfilling, they are cautious about doing so due to the high costs involved and naturally try to identify the most cost-effective means of doing so. Gomes et al. (2008) compared several different methods of biowaste separate collection and concluded that the costs incurred in the separate collection of whole biowaste and of biowaste generated in major urban communities were potentially lower than the costs involved in traditional collection of unsorted wastes. Thus, the implementation of biowaste separate collection schemes does not necessarily result in an increase of total costs for the municipal waste management system. Larsen et al. (2010) reported how curbside collection (and drop-off collection) was not only just as effective in increasing recycling rates, but also efficient in reducing the municipal costs of collection due to avoidance of high costs of incineration. However, Larsen et al. (2010) reported that recourse to recycling centers did not result in an appropriate increase of recycling rates. 
Collection costs are strongly influenced by the choice of waste trucks and relative fuel consumption. Bender et al. (2014) observed how the replacement of conventional diesel trucks by hybrid hydraulic waste vehicles capable of recovering, storing and reusing braking energy may result in significant cost savings. However, when evaluating the potential benefits of new vehicles, driving cycle and operational mode should also be given due consideration. The collection system is not only dependent on the type of vehicle, but also on vehicle routing in general, as confirmed by Eksioglu et al. (2009). To increase the efficiency of waste collection based on innovative and SMART routing Faccio et al. (2011), and Hannan et al. (2011) tested innovative traceability devices including RFID systems (Radio Frequency Identification), GPRS (General Packet Radio Service), and GPS technology (Global Positioning System), obtaining a positive outcome. Dynamic scheduling and routing through use of level sensors placed on containers and wireless communication equipment enabling waste operators to work with real-time data result in a reduction of operating costs by optimizing collection and hauling distances, and labor hours (Johansson, 2006).

The reliance of waste collection systems on securing a compromise between container policies based on volume, location, or frequency of shifts arrangements and vehicle settings was confirmed by Rodrigues et al. (2016). Teixeira et al. (2014) provided information relating to the efficiency of proactive short-term control of waste collection circuits as a suitable instrument for use in optimizing collections, with drop-off collections seen as the most effective and efficient means of collecting MSW.

To enhance collection efficiency Greco et al. (2015) suggested optimizing the location of collection points and the frequency of shifts. Workforce and vehicle usage likewise strongly impact collection efficiency (ibid). Mes et al. (2014) confirmed that by modifying routing parameters and adjusting them to fit with a range of different conditions as weather, or holidays it would be possible to achieve an optimization of the system (decrease of costs up to 40\%).

Fernández-Aracil et al. (2018) listed higher wages, coastal municipalities, tourist areas, population and separate collection as factors influencing the costs of managing municipal waste collections. Mandatory targets established by both the European Union and Spanish legal frameworks proved to be of high importance when analyzing the costs of municipal waste management systems.

\subsection{Biowaste collection in the city of Ústí nad Labem}

The separate collection of biowaste (based on containers) was introduced in 2016 following the response received to a campaign in which the population was asked to define changes they would like to see in the city. Biowaste containers (so-called 'compostainers') were introduced in the area of multi-family housing. The city of Ústí nad Labem implemented a pilot project in the city district "Severní Terasa" where 50 containers were located at collection points (drop-off collection) for recyclables (paper and cardboard, plastics, glass). In March 2017 the pilot project was extended to another 3 city districts ("City Centre", "Neštěmice", and "Střekov"). The city was equipped with
193 biowaste containers with a volume of 240 liters. The distribution of containers, which remains rather disparate, can be observed in Figure 1.

The introduction of a biowaste separate collection scheme was accompanied by an information campaign based on leaflets and website of the project. Furthermore, each container illustrated a list of the waste suitable and unsuitable for deposition in the container, the location of the container (address of the collection point), and details of how often and on which day of the week the container was emptied. In the context of the study conducted in the Neštěmice city district, an additional informational campaign was carried out between the collections of $5^{\text {th }}$ and $19^{\text {th }}$ October 2017 and a label was added to the container to inform the population of the inappropriacy of depositing plastic bags in the container

Following introduction of the scheme (pilot project) the containers were emptied on a weekly basis; . however, regular checks of the container content made by city workers at the end of the pilot phase led to a change in collection frequency to once a fortnight. Furthermore, the regular check indicated the potential risks of collection to be the presence of contaminants (especially paper, plastic bags, and other waste) or unused container volumes. Both these issues raised the following research questions:

- Would relocation of containers increase the efficiency of the system?

- How much would the costs of relocation amount to?

- Could an information campaign influence the amount of contamination?

\section{METHODOLOGY AND DATA}

\subsection{Data}

Data analysis was based on 11 bi-weekly field observations in the period from July $1^{\text {st }}$ to November $30^{\text {th }} 2017$. Each of the 4 city districts was equipped with 50 containers on average (193 containers throughout the whole city), with containers being emptied every 14-days. During the research period each container was checked by the research team one day prior to collection, incl. photo documentation of the container contents. Only visible content was checked, with no detailed composition of the waste). Furthermore, littering around the container (5-meter range) was recorded (Figure 2).

During the survey several significant differences were observed in the volume and quality of separated biowaste. The following figure shows that during the period analyzed the average volume of biowaste represented by average bin fill level was on a slight increase (with the exception of the first half of November), whereas the proportion of contaminated bins gradually decreased, resulting in a better overall quality of collected biowaste. The most frequent contaminant was plastic, followed by paper and municipal solid waste, with a combination of these three waste streams present in the majority of cases.

The authors were able to obtain data relating to the 937 households present in the area and the inhabitants at each address. Data were obtained from the city council. These data were used for the optimization of container loca- 


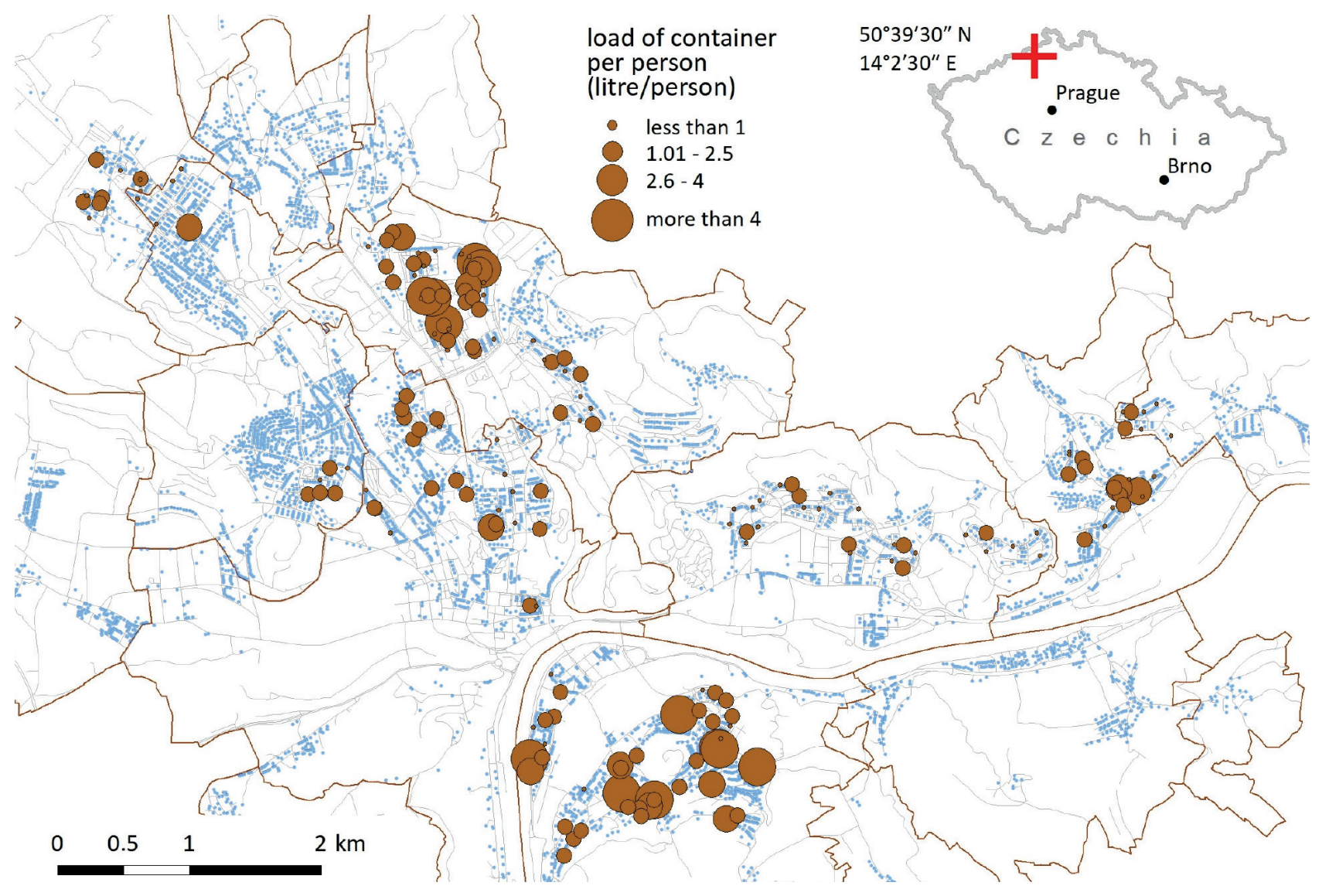

FIGURE 1: Distribution of containers in the city of Ústí nad Labem (liter per person). Source: own elaboration.

-Average bin fill level (in \%)

_Proportion of bins with contamination (in \%)

..... Linear trendline for average bin fill level

..... Linear trendline for proportion of bins with contamination

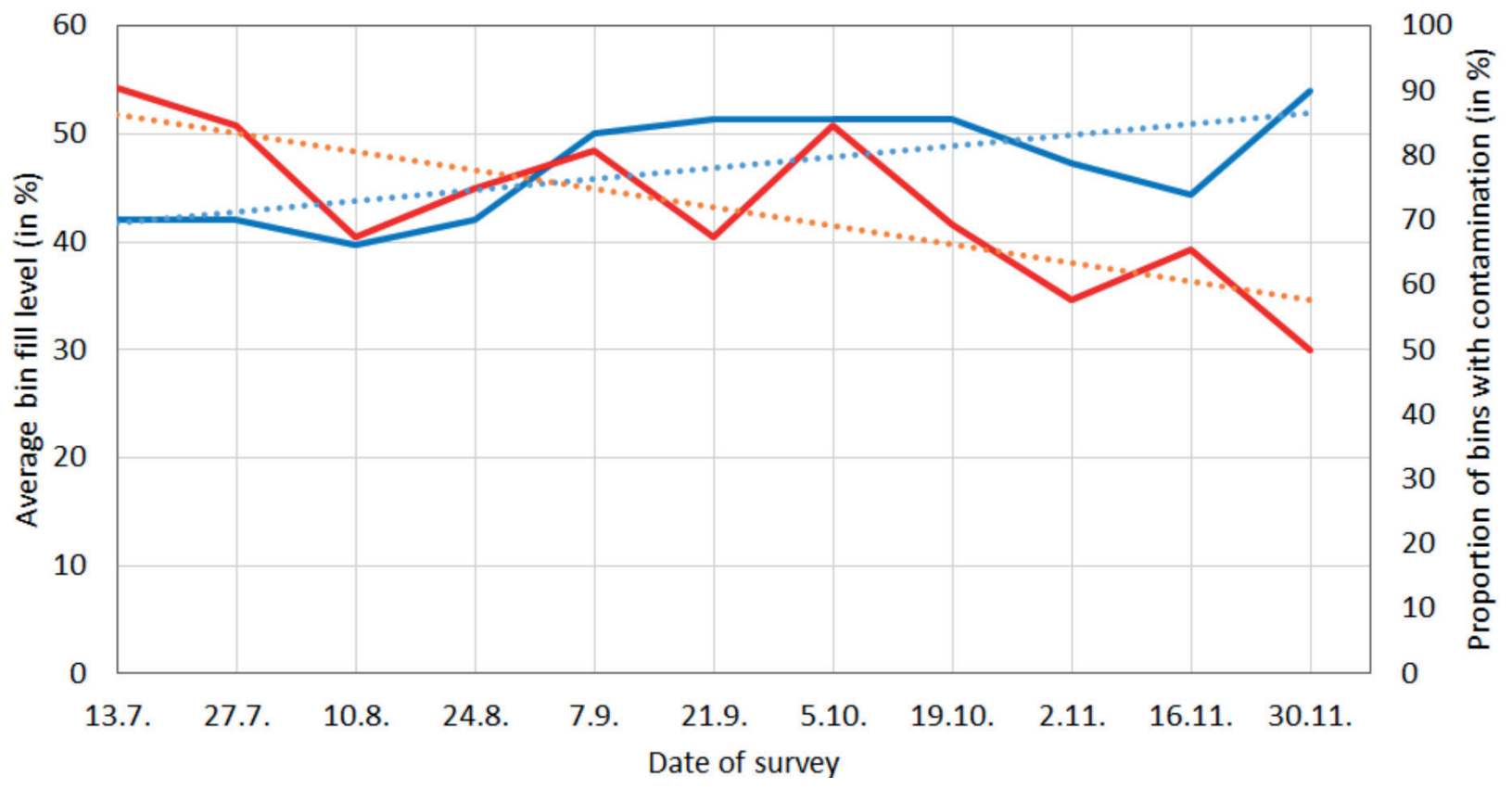

FIGURE 2: Development of average bin fill levels and proportion of bins with contamination in the study area Neštěmice, 13.7 / 30.11.2017 Source: own elaboration. 
tion throughout the city. The following assumptions were adopted:

- The closer the biowaste containers are to the households the better;

- The distance to biowaste containers should not exceed $134 \mathrm{~m}$, i.e. the maximum the inhabitants are willing to walk to the containers;

- The lower number of inhabitants using one container on average the better.

These assumptions represent the limitations of optimization - the convenience of the system was the main priority of municipal representatives, aimed at increasing public participation on biowaste separate collection and reducing contamination. As Sidique et al. (2010) and Struk (2017) stated the proximity of containers plays a significant role in raising public involvement in the municipal separate collection system. Furthermore, periodic evaluations of the recycling behavior of households ascertained that optimal distance is represented by an intersection between the average distance to the container and the distance that householders are willing to walk to reach the container. Thus the intersection between amount of containers in the system reported by municipalities and subjective perception of householders. While the average distance to the container is decreasing from year to year as municipalities try to equip the system with a higher number of containers, the willingness of householders to walk to the container is on an increase (EKO-KOM, 2017). The closer the containers to the place of residence, the greater the disturbance caused to households by noise (breaking glass, collection vehicles etc.). The number of inhabitants served by one container is an important indicator of system efficiency. The higher the number of inhabitants using one container, the higher the risk of overfilled containers, of contamination and of a potentially higher distance to containers. However this is not the case for blocks of flats.

\subsection{Methodology - case study of city area Neštěmice}

For the following analysis we selected one city district as a case study (Neštěmice, geographically incl. Krásné Březno). To assess the presence of potential differences in quality and quantity of biowaste deposited in containers before and after introduction of the information campaign in the district of Neštermice (as mentioned above, this was implemented between field observations on the 5th and 19th of October 2017) the chi-square test was used. This test was chosen due to the survey failing to provide precise information on the amount of biowaste contained in specific waste bins, yielding only estimations according to the following five categories: 1 . (almost) empty, 2. one third full, 3. one half full, 4. two thirds full and 5. full. Based on the latter estimations frequencies were calculated for the five above-mentioned categories; similarly, the quality of biowaste was evaluated according to the number of bins with and without contamination for each bi-weekly field observation.

The current location of biowaste containers and their availability was analyzed in GIS (ESRI 2011). Current availability based on walking distance to containers using a parameter of $134 \mathrm{~m}$ was assessed by means of Network Analyst tools. A network of streets was created, showing the addresses and respective number of inhabitants and destinations of biowaste containers. This setting allowed us to perform Service Area analysis, and to create specific regions or districts covering a perimeter of $134 \mathrm{~m}$ walking distance to biowaste containers (Scenario 1). Based specific individual regions we consecutively calculated the number of inhabitants present in each region.

Subsequently, we addressed the optimization of the location of containers $(n=50)$ as a second scenario, and calculated the optimal number of containers to cover the entire study area as a third scenario. Both scenarios were studied using Location-Allocation analysis. Randomly distributed points $(n=8000)$ were assigned to cover the entire study area at a distance of no more than $25 \mathrm{~m}$ from the road and served as candidate points for future best placement in the second and optimal relocation of containers from the first scenario. The outcomes of GIS analysis in the form of database tables were subsequently aggregated and summarized in R package "psych" (Revelle, 2018).

\section{RESULTS AND DISCUSSION}

The authors commenced by investigating the potential differences in biowaste quality prior to and following introduction of an additional information campaign. Biowaste quality is underpinned by the presence of contaminants in the waste bin. Using the chi-square test the observed and estimated frequencies were compared. Based on the results obtained $\left(x^{2}=21.273, p\right.$-value $\left.=0.000\right)$ the hypothesis whereby there were no differences in distribution prior to and following the information campaign was rejected and an association between introduction of the information campaign and biowaste contamination was confirmed. Table 1 illustrates how the campaign contributed towards increasing the quality of biowaste produced even though the majority of bins remained contaminated.

To assess the effect of the information campaign on waste quantity the authors again applied the chi-square

TABLE 1: Distribution of bins with and without contamination before and after the launch of information campaign (Neštěmice, 13.7 / 30.11.2017). Source: own calculation.

\begin{tabular}{|c|c|c|c|c|c|}
\hline & \multicolumn{2}{|c|}{ 7.10. and before } & \multicolumn{2}{|c|}{ 19.10. and after } & Total \\
\hline & Count & Percent (\%) & Count & Percent (\%) & Count \\
\hline Bins with contamination & 287 & 79 & 126 & 61 & 413 \\
\hline Bins without contamination & 77 & 21 & 82 & 39 & 159 \\
\hline Total & 364 & 100 & 208 & 100 & 572 \\
\hline
\end{tabular}


test, revealing a difference in the distribution of bin fill levels prior to and following introduction of the campaign $\left(x^{2}\right.$ $=16.563$, $p$-value $=0.002$ ). However, based on the distribution of frequencies in particular categories it cannot merely be confirmed that introduction of the campaign led to higher fill levels of bins, although a higher proportion of half-full bins and, on the contrary, a lower percentage of (almost) empty bins was observed after October $19^{\text {th }} 2017$ (Table 2).

Our preliminary results show how a target-oriented information campaign may contribute towards increasing the amount of biowaste deposited in containers (important for the efficiency of collection) and reducing contamination of the container content (important for disposal/ treatment operators). Both short-term and one-off information campaigns prior to start-up of separate collection and a long-term campaign that reflects running experience and evaluates system performance should be envisaged (see Grodzinska-Jurzak et al., 2006). Although instrumental knowledge, thus what to separate and where, is enhanced by the campaign (De Feo and De Gisi, 2010), rather than providing an extensive amount of information on separation, awareness should be raised by focusing on inhabitants (Bernstad, 2014). However, there are no general recommendations as to how the information campaign should be prepared. Campaigns should reflect local conditions as the structure of inhabitants, type of housing, accessibility of containers etc., and therefore 'one size does not fit all' (Lakhan, 2014).

With regard to the issue of biowaste composting, the contamination of biowaste in containers is a rather serious problem. A working hypothesis was used, according to which the location of biowaste containers at collection points for recyclables (paper and cardboard, plastics, and glass), particularly in the area of multi-family housing generates a perverse behavior amongst inhabitants. High levels of anonymity in this type of housing lessen the pressure of social norms (Barr et al., 2003) and therefore, increase the probability of improper disposal. Furthermore, organization of the separate collection of recyclables and its parameters is crucial (volume of bins, frequency of shifts). When the containers for recyclables are overfilled, the recyclables are deposited in biowaste containers. In particular paper, plastics - especially bags, or PET bottles, but also clothes and some types of bulky waste are the main contaminants. Deposition of a certain amount of contaminants in biowaste containers is understandable - e.g. plas- tic bags used to transport the biowaste or clothes made from natural materials. For this reason, additional information campaigns devoted to increasing instrumental knowledge should be set up. Indeed, appropriate optimization of the separate collection of recyclables may in turn elicit a substantial increase in the effectiveness of biowaste separate collection.

In the case of optimizing the location of containers we investigated 3 scenarios that respected the $134 \mathrm{~m}$ limit between place of abode and container. Scenario 1 worked to the assumption that the location of containers remained the same. Scenario $2 a$ assumed that the 50 containers available in the city district Neštěmice were relocated to better serve as many address points in the area as possible. Scenario $2 \mathrm{~b}$ assumed that the 50 containers available in the city district Neštěmice were relocated to better cover as many inhabitants in the whole area as possible. In both scenarios 8,000 randomly distributed points in the area were proposed as candidate positions for the relocation of 50 containers in respect of the $134 \mathrm{~m}$ limit. Scenario 3 worked to the assumption that the population of the area should be completely covered, even if it would be necessary to acquire more containers to achieve this. Eight thousand randomly distributed points were once again selected in the area and were used as candidate positions for the location of containers in respect of the $134 \mathrm{~m}$ limit. The results are summarized in Table 3.

The results obtained with regard to the relocation of containers in Scenarios $2 a, 2 b$, and 3 resulted in a higher number of addresses having access to biowaste containers. The relocation of containers (Scenarios $2 a, 2 b$ ) increased both the number of address points and number of inhabitants equipped with biowaste containers within a distance of max. $134 \mathrm{~m}$. Compared to Scenario 1 the number of address points in Scenario $2 a$ increased by about $107.18 \%$, while the number of inhabitants in Scenario $2 b$ increased by about $32.30 \%$. By covering the whole city district with an additional 55 containers (Scenario 3) the number of address points increased by approx. $149.20 \%$ and the number of inhabitants by about $38.14 \%$ (however, the increase in number of inhabitants between Scenario $2 b$ and 3 is only slight).

The negative side effect of Scenarios 2a and 2b (linking a greater number of address points and inhabitants to the separate collection system) lies in the increasing number of inhabitants per container with the previously mentioned

TABLE 2: Distribution of bin fill level before and after the launch of information campaign, Neštěmice, 13.7.-30.11.2017. Source: own calculation.

\begin{tabular}{|c|c|c|c|c|c|}
\hline & \multicolumn{2}{|c|}{ 7.10. and before } & \multicolumn{2}{|c|}{ 19.10. and after } & \multirow[b]{2}{*}{ Coun } \\
\hline & Count & Percent (\%) & Count & Percent (\%) & \\
\hline (Almost) empty & 61 & 17 & 16 & 8 & 77 \\
\hline $1 / 3$ full & 123 & 34 & 71 & 34 & 194 \\
\hline $1 / 2$ full & 66 & 18 & 61 & 29 & 127 \\
\hline $2 / 3$ full & 60 & 17 & 37 & 18 & 97 \\
\hline Full & 51 & 14 & 26 & 12 & 77 \\
\hline Total & 361 & 100 & 211 & 100 & 572 \\
\hline
\end{tabular}




\begin{tabular}{|c|c|c|c|c|}
\hline & Scenario 1 & Scenario $2 a$ & Scenario $2 b$ & Scenario 3 \\
\hline $\begin{array}{l}\text { Number of addresses covered by } \\
\text { containers (with max. distance of } 134 \mathrm{~m} \text { ) }\end{array}$ & 376 & 779 & 687 & 937 \\
\hline $\begin{array}{l}\text { Number of inhabitants with access to the } \\
\text { container (with max. distance of } 134 \mathrm{~m} \text { ) }\end{array}$ & 15,566 & 17,700 & 20,594 & 21,503 \\
\hline \multicolumn{5}{|l|}{ Number of inhabitants/container } \\
\hline min. & 81 & 20 & 57 & 2 \\
\hline $\max$ & 772 & 920 & 920 & 826 \\
\hline SD & 155 & 293 & 203 & 212 \\
\hline mean & 311 & 354 & 412 & 205 \\
\hline median & 274 & 287 & 426 & 140 \\
\hline \multicolumn{5}{|l|}{ Distance to the container (m) } \\
\hline $\min$. & 2.24 & 1.70 & 0.1 & 0 \\
\hline $\max$ & 133.85 & 133.95 & 133.95 & 133.84 \\
\hline SD & 35.14 & 35.07 & 35.47 & 36.08 \\
\hline mean & 73.94 & 78.97 & 78.34 & 61.68 \\
\hline median & 74.82 & 82.19 & 61.68 & 59.51 \\
\hline
\end{tabular}

risks as overfilling or contamination, and in the extended distance to the container (about $5 \mathrm{~m}$ on average). Howev$\mathrm{er}$, the maximum distance to the container remained within the limit of $134 \mathrm{~m}$, implying the convenience of the separate collection system for households.

The introduction of new containers into the system (Scenario 3) produces positive effects not only on the decreasing number of inhabitants per container (about $34.08 \%$ ), but also on the lesser distance to the container (approx. $12.26 \mathrm{~m}$ on average in comparison with Scenario 1). These effects influence positively the cost and benefits analysis of the new biowaste separate collection system, although to what extent may not be simple to calculate. Furthermore, these positive effects indicate the increased convenience for inhabitants when opting to separate biowaste (Figure 3).

Convenience however is not the sole aspect to play a significant role in the decision of local representatives with regard to improvements to the separate collection system. The relocation of containers will also impinge on collection costs. Table 4 summarizes the calculation of costs imposed by the relocation of containers according to Scenarios $2 a, 2 b$, and 3 . The relocation of containers results in the reduction of distance from/to the plant to the first/from the last container in the city. However, the total distance driven by the collection vehicle increases in Scenarios $2 a$, $2 b$, and particularly in Scenario 3. The reason for this lies in the higher distance driven by the collection vehicle in the city when an increased number of address points and inhabitants need to be served. We envisage the need for 26 pick-ups per year (collection frequency every 14 days) and an average weight of biowaste amounting to $258 \mathrm{~kg} /$ $\mathrm{m}^{3}$ (Marešová and Slejška, 2006). Based on our experience from data collection we assume the average fill level of the container to be in the range of $47-55 \%$ (Scenario $2 a, 2 b$ ), and $40-50 \%$ (Scenario 3).

The results of our cost analysis confirmed that the re- location of containers aimed at increasing the number address points and inhabitants would result in an increase in collection costs, with increased total costs of approx. $20.65 \%$ (Scenario $2 a$ ), or $8.84 \%$ (Scenario 2 b), respectively. When new equipment is needed (Scenario 3 ), total costs increase substantially (total costs almost five times higher compared to Scenario 1). Nevertheless, a higher generation of biowaste is expected in Scenario 3, thus the average cost per ton will assume a higher significance for decision makers. On linking a higher number of address points on the separation collection system, as a consequence, higher amounts of biowaste will be generated simultaneously and the average cost per ton will increase by approx. $8.47 \%$ (Scenario 2a). When involving a higher number of inhabitants (Scenario 2b) who deposit more biowaste in containers, the average cost per ton decreases by approx. $6.36 \%$. In Scenario 3, when the separate collection system is equipped with an additional 55 containers, a higher number of address points and inhabitants are served by the system, thus higher amounts of biowaste are generated. The average cost per ton range from 48.5 EUR/ton (105.5\% increase in comparison with Scenario 1) to $60.6 \mathrm{EUR} / \mathrm{ton}$ (156.78\% increase in comparison with Scenario 1).

\section{CONCLUSIONS}

The experience gained on a municipal level has confirmed how the European regulation of biodegradable municipal waste (biowaste) treatment places a significant demand on local systems of biowaste separation. Two issues in particular should be addressed, namely: how to implement systems that contribute towards achieving the targets established by the European environmental regulations with respect to high levels of public engagement, and how to balance the municipal budget for waste management. The case study of the city Ústí nad Labem confirmed that this is not a simple task. The implementation of container-based separate collection of biowaste raised 

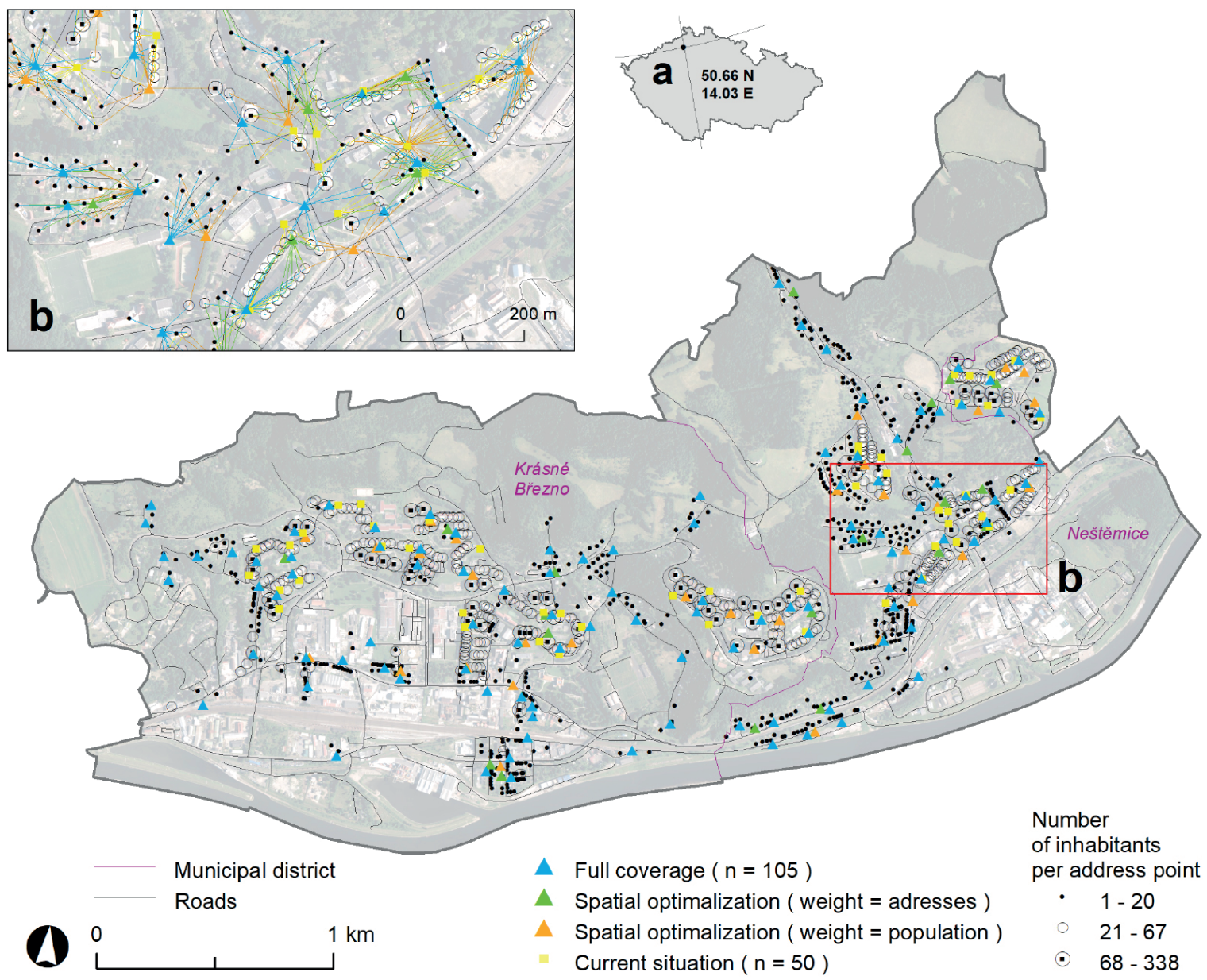

FIGURE 3: Number of inhabitants per address point for each scenario. Source: own elaboration.

TABLE 4: Collection cost analysis for each scenario. Source: own calculation.

\begin{tabular}{|c|c|c|c|c|}
\hline & Scenario 1 & Scenario 2A & Scenario 2B & Scenario 3 \\
\hline Number of containers & 50 & 50 & 50 & 105 \\
\hline new containers needed & NO & NO & NO & YES (55) \\
\hline $\begin{array}{l}\text { Distance driven by car within city } \\
\text { district }(\mathrm{km})\end{array}$ & 17.1 & 23.8 & 20.2 & 33.6 \\
\hline $\begin{array}{l}\text { distance driven by car from the } \\
\text { plant }(\mathrm{km})\end{array}$ & 8.3 & 7.9 & 8.0 & 8.2 \\
\hline $\begin{array}{l}\text { Distance driven by car to the plant } \\
\qquad(\mathrm{km})\end{array}$ & 8.3 & 8.2 & 8.1 & 7.9 \\
\hline Distance total & 33.7 & 39.9 & 36.3 & 49.7 \\
\hline Number of pick-ups per year & 26 & 26 & 26 & 26 \\
\hline Average bin fill level & $47 \%$ & $47-55 \%$ & $47-55 \%$ & $40-50 \%$ \\
\hline Average weight of $\mathrm{m}^{3}$ of biowaste & 258 & 258 & 258 & 258 \\
\hline \multicolumn{5}{|c|}{ COSTS (EUR) } \\
\hline Containers (240 I/50,2 eur) & 0.0 & 0.0 & 0.0 & 2758.4 \\
\hline Costs of driving within city district & 435.1 & 605.6 & 514.0 & 855.0 \\
\hline $\begin{array}{l}\text { Costs of driving from and to the } \\
\text { plant }\end{array}$ & 328.5 & 318.6 & 318.6 & 318.6 \\
\hline Amortization & 129.9 & 153.8 & 140.0 & 191.6 \\
\hline Total & 893.6 & $1,078.1$ & 972.6 & $4,123.6$ \\
\hline Tons of biowaste & 38 & $38-44$ & $38-44$ & $68-85$ \\
\hline Average costs per ton & 23.6 & $28.4-24.5$ & $25.6-22.1$ & $60.6-48.5$ \\
\hline
\end{tabular}


specific problems linked to the contamination of container content, thus rendering the use of organic matter for other treatments (i.e. composting) difficult. This is largely ascribable to the way in which the population is involved in the system and in the organization of the separate collection of other recyclables. The separate collection of biowaste involves an inappropriate type of housing with high levels of anonymity, biowaste containers are located at collection points for other recyclables, and there is a high proximity to biowaste containers in some areas. Furthermore, the separate collection of other recyclables is characterized by a misleading frequency of the collection of recyclables, or improper volume of containers for other recyclables - paper and cardboard, plastics, glass. We demonstrate that a target-oriented information campaign is capable of reducing the amount of contamination. However, in the long-term the additional information campaign is not able to replace the absence of social norms. Therefore, the relocation of biowaste containers to comply with the respect to type of housing should be implemented.

The potential relocation of containers will result in an increase of the number of address points and inhabitants linked to the separate collection system. The introduction of new containers into the system with the aim of covering all address points in the city district reduces the distance to the container and therefore increases the convenience of the system. Furthermore, the risk of linking a high number of inhabitants to one sole container (contamination or overfilling) will consequently decrease. The simple relocation of containers in the system will not provide any additional positive effects with regard to the number of inhabitants served by one container or the distance to the container.

In particular, the evaluation of costs will be crucial for the decision makers at local level. The results obtained in this study confirmed that a higher convenience in separate collection would not come free of charge. An increased proximity of containers would produce a rise in collection costs (transport, containers), with relocation of containers for the purpose of increasing the number of inhabitants served by the system impinging positively on cost.

Further studies should be undertaken to evaluate the direct and indirect costs needed to optimize the biowaste system and to identify the benefits of the same. An overall cost analysis based on the use of GIS may represent a suitable instrument for use in the optimization of biowaste waste collection systems. From the point of view of municipal representatives, this kind of analysis may contribute towards supporting extension of biowaste separate collection. However, additional instruments to be applied at a national level should be identified (landfill taxes, landfill closure, etc.).

\section{ACKNOWLEDGEMENTS}

The Authors would like to thank the Czech Science Foundation for financial support of the project No. 1614409S 'Demographic development and behavioral aspects (e.g. 'crowding-out effect') and their impact on the municipal waste charging policy'.

\section{REFERENCES}

Amponsah, S.K., Salhi, S. 2004. The investigation of a class of capacitated arc routing problems: the collection of garbage in developing countries. Waste Manag. 24, 711-721. https://doi.org/10.1016/j. wasman.2004.01.008

Barr, S., Ford, N.J., Gilg, A. 2003. Attitudes towards recycling household waste in Exeter, Devon: quantitative and qualitative approaches. Local Env. 8, 407-421. https://doi.org/10.1080/13549830306667

Bernard-Beltrán, D., Simó, A., Bovea, M.D. 2014. Attitude towards the incorporation of the selective collection of biomeste in a municipal solid waste management system. A case study. Waste Manag. 34, 2434-2444. http://dx.doi.org/10.1016/j.wasman.2014.08.023

Bernstad, A., la Cour Jansen, J., Aspegren, A. 2013. Door-stepping as a strategy for improved food waste recycling behaviour - Evaluation of full-scale experiment. Resour. Conserv. Recy. 73, 94-103. https://doi.org/10.1016/j.resconrec.2012.12.012

Bernstad, A. 2014. Household food waste separation behaveor and the importance of convenience. Waste Manag. 34, 1317-1323. https:// doi.org/10.1016/j.wasman.2014.03.013

Bender, F.A., Bosse, T., Sawodny, O. 2014. An investigation on the fuel savings potential of hybrid hydraulic refuse collection vehicles. Waste Manag. 34, 1577-1583. http://dx.doi.org/10.1016/j.wasman.2014.05.022

Dahlén, L., Vukicevic, S., Meijer, J.-E., Lagerkvist, A. 2007. Comparison of different collection systems for sorted household waste in Sweden. Waste Manag. 27, 1298-1305. https://doi.org/10.1016/j.wasman.2006.06.016

Dahlén, L., Lagerkvist, A. 2010. Evaluation of recycling programmes in household waste collection systems. Waste Manage. Res. 28, 577587. https://doi.org/10.1177/0734242X09341193

De Feo, G., De Gisi, S. 2010. Public opinion and awareness towards MSW and separate collection programmes: A sociological procedure for selecting areas and citizens with a low level of knowledge. Waste Manag. 30, 958-976. https://doi.org/10.1016/j.wasman.2010.02.019

Domina, T., Koch, K. 2002. Convenience and frequency of recycling: Implications for including textiles in curbside recycling programs. Environ. Behav. 34, 216-238. https://doi.org/10.1177/001391650 2034002004

EKO-KOM. 2017. The interview with Lukáš Grolmus (the chief of communication department of the recovery organization EKO-KOM) that took place at 23.11.2017

Eksioglu, B., Vural, A.V., Reisman, A. 2009. The vehicle routing problem: A taxonomic review. Comput. Ind. Eng. 57, 1472-1483, https://dio. org/10.1016/j.cie.2009.05.009

ESRI. 2011. ArcGIS Desktop: Release 10. Redlands, CA: Environmental Systems Research Institute.

Faccio, M., Persona, A., Zanin, G. 2011. Waste collection multi objective model with real time traceability data. Waste Manag. 31, 23912405. https://doi.org/10.1016/j.wasman.2011.07.005

Fernández-Aracil, P., Ortuno-Padilla, A., Melgarejho-Moreno, J. 2018. Factors related to municipal costs of waste collection service in Spain. J. Clean. Prod. 175, 553-560. https://doi.org/10.1016/j.jclepro.2017.12.116

Gallardo, A., Bovea, M.D., Colomer, F.J., Prades, M., Carlos, M. 2010. Comparison of different collection systems for sorted household waste in Spain. Waste Manag. 30, 2430-2439. https://doi. org/0.1016/j.wasman.2010.05.026

Gomes, A.P., Matos, M.A., Carvalho, I.C. 2008. Separate collection of the biodegradable fraction of MSW: An economic assessment. Waste Manag. 28, 1711-1719. https://doi.org/10.1016/j.wasman.2007.08.017

González-Torre, P.L., Adenso-Díaz, B., Ruiz-Torres, A. 2003. Some comparative factors regarding recycling collection systems in regions of the USA and Europe. J. Environ. Manage. 69, 129-138. https:// doi.org/10.1016/S0301-4797(03)00109-9

González-Torre, P.L., Adenso-Díaz, B. 2005. Influence of distance on the motivation and frequency of household recycling. Waste Manag. 25, 15-23. https://doi.org/10.1016/j.wasman.2004.08.007

Greco, G., Allegrini, M., Del Lungo, C., Savellini, P.G., Gabellini, L. 2015 Drivers of solid waste collection costs. Empirical evidence from Italy. J. Clean. Prod. 106, 364-371. http://dx.doi.org/10.1016/j.jclepro.2014.07.011 
Grodzinska-Jurczak, M., Tomal, P., Tarabula-Fiertak, M., Nieszporek, K., Read, A.D. 2006. Effects of an educational campaign on public environmental attitudes and behaviour in Poland. Resour. Conserv. Recy. 46, 182-197.

Hage, O., Söderholm, P. 2008. An econometric analysis of regional differences in households waste collection: The case of plastic packaging waste in Sweden. Waste Manag. 28, 1720-1731. https://doi. org/10.1016/j.wasman.2007.08.022

Hannan, M.A., Arebey, M., Begum, R.A., Basri, H. 2011. Radio Frequency Identification (RFID) and communication technologies for solid waste bin and trick monitoring system. Waste Manag. 31, 24062413. https://doi.org/10.1016/j.wasman.2011.07.022

Johansson, O.M. 2006. The effect of dynamic scheduling and routing in a solid waste management system. Waste Manag. 26, 875-885. https://doi.org/10.1016/j.wasman.2005.09.004

Lakhan, C. 2014. Exploring the relationship between municipal promotion and education investments and recycling rate performance in Ontario, Canada. Resour. Conserv. Recy. 92, 222-229. http://dx.doi. org/10.1016/j.resconrec.2014.07.006

Larsen, A.W., Merrild, H., Møller, J., Christensen, T.H. 2010. Waste collection systems for recyclables: an environmental and economic assessment for the municipality of Aarhus (Denmark). Waste Manag. 30, 744-754. https://doi.org/10.1016/j.wasman.2009.10.021

Marešová, K., Slejška, A. 2006. Výsledky pilotního projektu v Uherském Hradišti sledujícím nakládání s bioodpadem. Biom.cz [online]. [Accessed: 2018-11-22]. Available from: <https://biom.cz/cz/ odborne-clanky/vysledky-pilotniho-projektu-v-uherskem-hradistisledujicim-nakladani-s-bioodpadem>.

Mattson Petersen, C.H., Berg, P.E.O. 2004. Use of recycling stations in Borlänge, Sweden - volume weights and attitudes. Waste Manag. 911-918. https://doi.org/10.1016/j.wasman.2004.04.002
Mes, M., Schutten, M., Rivera, A.P. 2014. Inventory routing for dynamic waste collection. Waste Manag. 34, 1564-1576. ttp://dx.doi. org/10.1016/j.wasman.2014.05.011

Rada, E.C., Ragazzi, M., Fedrizzi, P. 2013. Web-GIS oriented systems viability for municipal solid waste selective collection optimization in developed and transient economies. Waste Manag. 33, 785-792. https://doi.org/10.1016/j.wasman.2013.01.002

Revelle, W. 2018. psych: Procedures for personality and psychological research. Northwestern University, Evanston, Illinois, USA. https:// CRAN.R-project.org $/$ package $=$ psych Version $=1.8 .4$.

Rodrigues, S., Martinho, G., Pires, A. 2016. Waste collection systems. Part A: a taxonomy. J. Clean. Prod. 113, 374-387. http://dx.doi. org/10.1016/j.jclepro.2015.09.143

Rousta, K., Bolton, K., Lundin, M., Dahlén, L. 2015. Quantitative assessment of distance to collection point and improved sorting information on source separation of household waste. Waste Manag. 40, 22-30. http://dx.doi.org/10.1016/j.wasman.2015.03.005

Saphores, J.D., Nixon, H. 2014. How effective are current household recycling policies? Results from a national survey of U.S. households. Resour. Conserv. Recy. 92, 1-10. https://doi.org/10.1016/j. resconrec.2014.08.010

Sidique, S.F., Lupi, F., Joshi, S.V. 2010. The effects of behavior and attitudes on drop-off recycling activities. Resour Conserv Recy. 54, 163-170. https://doi.org/10.1016/j.resconrec.2009.07.012

Simonetto, E. O., Borenstein, D. 2007. A decision support system for the operational planning of solid waste collection. Waste Manag. 27, https://doi.org/10.1016/j.wasman.2006.06.012

Teixeira, C.A., Avelino, C., Ferreira, F., Bentes, I. 2014. Statistical analysis in MSW collection performance assessment. Waste Manag. 34, 1584-1594. http://dx.doi.org/10.1016/j.wasman.2014.04.007 